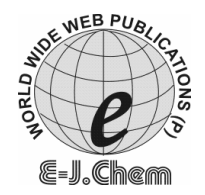

http://www.e-journals.net
ISSN: 0973-4945; CODEN ECJHAO

E-Journal of Chemistry 2009, 6(3), 770-774

\title{
Synthesis and Antimicrobial Activity of Some Derivatives of 5-Substituted Indole Dihydropyrimidines
}

\author{
L. C. HEDA, RASHMI SHARMA, \\ C. PAREEK and P. B. CHAUDHARI* \\ Research Laboratory, \\ Department of Chemistry, S.D. Govt. College, \\ Beawar, 305901, Rajasthan, India. \\ prmdchaudhari@yahoo.co.in
}

Received 27 December 2008; Accepted 25 February 2009

\begin{abstract}
P. Biginelli reported the synthesis of functionalized 3, 4 dihydropyrimidine$2(1 H)$-ones via three component condensation of an aromatic aldehyde, urea and ethylacetoacetate. This multicomponent reaction is of much importance due to excellent pharmacological properties of dihydropyrimidines. In this account, we synthesized some halo substituted indole dihydropyrimidines and evaluated their antimicrobial activity. The minimum inhibitory concentration (MIC) was determined by micro dilution technique in Mueller-Hinton broth. The MICs were recorded after 24 hours of incubation at $37{ }^{\circ} \mathrm{C}$. These results are promising, showing these compounds are biologically active.
\end{abstract}

Keywords: Substituted indoles, Dihydropyrimidines, Biginelli Reaction, Multicomponent reaction.

\section{Introduction}

In the family of heterocyclic compounds nitrogen containing heterocycles are an important class of compounds in the medicinal chemistry and also contributed to the society from biological and industrial point which helps to understand life processes ${ }^{1}$. This seems to be because pyrimidines represents one of the most active class of compounds possessing wide spectrum of biological activity viz. significant in vitro activity against unrelated DNA and RNA, viruses including polio herpes viruses, diuretic, antitumor, anti HIV, cardiovascular ${ }^{2}$. Biginelli compounds show a diverse range of biological activities. The interest focused on Biginelli compounds leading to the development of nitractin $(\mathrm{A})^{3}$, that has excellent activity against the virus of trachoma group, the same compounds also exhibit antibacterial activity. 4-Aryl dihydropyrimidines e.g. nifedipine (B) are the important and most studied class as 
calcium channel modulars. In 1975 their introduction in clinical medicine for the treatment of cardiovascular diseases ${ }^{4}$, some of the analogues were screened as antitumor agents. Pyrimidine -5-carboxamide of type (C) was reported to possess anticarcinogenic activity, anti-inflammatory ${ }^{5}$, analgesic ${ }^{6}$.

The topsentins, as antiviral and antitumor agents from marine sponge represents the emerging class of bis indole alkaloids. During the search of bioactive natural products act as cytotoxic and antifungal compounds belongs to class noprtopsentins ${ }^{7}$. The presence of highly substituted indole and indolines in a variety of bioactive molecular targets has inspired a number of groups including ours to develop new and improved routes to their synthesis ${ }^{8}$. Recently there is a much interest in the synthesis of small molecules for chemist in accelerating drug discovery'.<smiles>COC(=O)C1C(C)NC(=O)NC1c1ccc(C)o1</smiles>

A

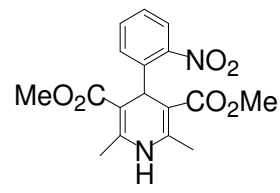

B

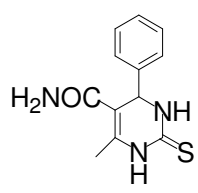

$\mathrm{C}$

\section{Experimental}

\section{General procedure for synthesis of subtituted indole-3-carboxaldehyde (3)}

To dimethyl formamide in ice bath, $\mathrm{POCl}_{3}$ was added drop wise by maintaining temperature below $10{ }^{\circ} \mathrm{C}$. After the addition, the mixture was stirred for $0.5 \mathrm{~h}$. To this formylation complex, solution of indole ( $\mathbf{1}$ or $\mathbf{2}$ ) in DMF was added. During addition temperature was maintained below $10{ }^{\circ} \mathrm{C}$. Then the temperature of the reaction mixture was brought to $35^{\circ} \mathrm{C}$ slowly and maintained for $1 \mathrm{~h}$. Then it was cooled to $10{ }^{\circ} \mathrm{C}$ and $\mathrm{NaOH}$ solution was added till alkaline. The resulting suspension was heated to $60{ }^{\circ} \mathrm{C}$ and allowed to cool to room temperature. It was filtered and washed with water.

\section{1-H-Indole -3-carboxaldehyde (3a)}

M.p.198 ${ }^{0}$ C; I.R. (KBr pellet): 3460, 3201, 3114, 3083, 2895, 2716, 1627, 1535, 1443, 1235 , $787 \mathrm{~cm}^{-1} ;{ }^{1} \mathrm{H}$ NMR (DMSO- $\left.d_{6}\right): \delta 7.23\left(2 \mathrm{H}, \mathrm{br}, \mathrm{H}^{5}\right.$ and $\left.\mathrm{H}^{6}\right), 7.52\left(1 \mathrm{H}, \mathrm{s}, \mathrm{H}^{7}\right), 8.17(1 \mathrm{H}, \mathrm{s}$, $\left.\mathrm{H}^{4}\right), 8.35\left(1 \mathrm{H}, \mathrm{s}, \mathrm{H}^{2}\right), 9.95(1 \mathrm{H}, \mathrm{s}, \mathrm{CHO}), 12.20(\mathrm{H}, \mathrm{s}, \mathrm{NH})$. Elemental analysis calc. (\%) C 74.47, H 4.86, N 9.65, O 11.02 found C 74.43, H 4.82, N 9.61, O 11.04.

\section{5-Bromo-1H-indole -3-carboxaldehyde (3b)}

M.p.202 ${ }^{0}$ C; I.R. (KBr pellet): 3440, 3215, 3103, 3058, 2833, 2773, 1647, 1581, 1535, 1444, $1235,736 \mathrm{~cm}^{-1} ;{ }^{1} \mathrm{H}$ NMR (DMSO- $\left.d_{6}\right): \delta 7.40\left(1 \mathrm{H}, \mathrm{s}, \mathrm{H}^{6}\right), 7.52\left(1 \mathrm{H}, \mathrm{s}, \mathrm{H}^{7}\right), 8.22\left(1 \mathrm{H}, \mathrm{s}, \mathrm{H}^{4}\right)$, $8.35\left(1 \mathrm{H}, \mathrm{s}, \mathrm{H}^{2}\right), 9.95(1 \mathrm{H}, \mathrm{s}, \mathrm{CHO}), 12.20(1 \mathrm{H}, \mathrm{s}, \mathrm{NH})$. Elemental analysis calc. $(\%) \mathrm{C}$ 48.25, H 2.70, N 6.25, O 7.14, found C 48.23, H 2.71, N 6.21, O 7.16.

\section{5-Chloro-1H-indole-3-carboxaldehyde (3c)}

M.p.200 ${ }^{0}$ C; I.R. (KBr pellet): 3435, 3200, 3102, 2940, 1650, 1560, 1452, 1213, 790, $735 \mathrm{~cm}^{-1}$ NMR (DMSO- $d_{6}$ ): $\left.\left.\delta 7.42\left(1 \mathrm{H}, \mathrm{s}, \mathrm{H}^{6}\right), 7.551 \mathrm{H}, \mathrm{s}, \mathrm{H}^{7}\right), 8.251 \mathrm{H}, \mathrm{s}, \mathrm{H}^{4}\right), 8.381 \mathrm{H}, \mathrm{s}$, $\mathrm{H}^{2}$ ), $\left.\left.9.981 \mathrm{H}, \mathrm{s}, \mathrm{CHO}\right), 12.24 \mathrm{HH}, \mathrm{s}, \mathrm{NH}\right)$. Elemental analysis calc. (\%) C 60.19, H 3.37, N 7.80, O 8.91, found C 60.16, H 3.35, N 7.78, O 8.89. 


\section{5-Iodo-1H-indole-3-carboxaldehyde (3d)}

M.p.220 ${ }^{0}$ C; I.R. (KBr pellet): 3445, 3201, 3114, 3083, 2895, 2716, 1627, 1535, 1443, $1235,787 \mathrm{~cm}^{-1}$; $1 \mathrm{H}$ NMR (DMSO- $\left.d_{6}\right): \delta 7.40\left(1 \mathrm{H}, \mathrm{s}, \mathrm{H}^{6}\right), 7.55\left(1 \mathrm{H}, \mathrm{s}, \mathrm{H}^{7}\right), 8.25\left(1 \mathrm{H}, \mathrm{s}, \mathrm{H}^{4}\right)$, $8.42\left(1 \mathrm{H}, \mathrm{s}, \mathrm{H}^{2}\right), 9.96(1 \mathrm{H}, \mathrm{s}, \mathrm{CHO}), 12.26(1 \mathrm{H}, \mathrm{s}, \mathrm{NH})$. Elemental analysis calc. (\%) C 39.88, H 2.23, N 5.17, O 5.90, found C 39.84, H 2.21, N 5.19, O 5.88.

\section{General procedure for the synthesis of indole dihydropyrimidine (6)}

A mixture of indole -3-carboxaldehyde 3 (1 eq), urea or thiourea 4 (2 eq), ethylacetoacetate 5 ( $1 \mathrm{eq})$ in ethanol was heated under reflux in the presence of acid catalyst. TLC was used to monitor the progress of the reaction. After completion the reaction mixture was poured on crushed ice and filtered under suction, the precipitate was washed with water. The pure product is obtained by recrystallization from ethanol.

4-(5-Bromo- $1 \mathrm{H}$ - indole-3-yl)-6-methyl-2-oxo-1, 2,3,4-tetrahydro-pyrimidine5-carboxylic acid ethyl ester (6b)

IR (KBr pellet): $3215,3100,3060,1710,1650,1525,1450,1230,1095,750 \mathrm{~cm}^{-1} ;{ }^{1} \mathrm{H}$ NMR $\left(\mathrm{DMSO}-d_{6}\right): \delta 1.18\left(3 \mathrm{H}, \mathrm{t}, \mathrm{OCH}_{2} \mathrm{CH}_{3}\right), 2.35\left(3 \mathrm{H}, \mathrm{s}, \mathrm{CH}_{3}\right), 4.05\left(2 \mathrm{H}, \mathrm{q}, \mathrm{OCH}_{2} \mathrm{CH}_{3}\right), 6.30(1 \mathrm{H}$, $\mathrm{NHCH}), 6.75-7.20(6 \mathrm{H}, \mathrm{br}, \mathrm{Ar}-\mathrm{H})$ and $\mathrm{NH}), 7.92(\mathrm{H}, \mathrm{s}, \mathrm{NH})$. Elemental analysis calc. (\%) C 50.81, H 4.26, N 11.11, O 12.69, found C 50.80, H 4.23, N 11.09, and O 12.66.

\section{4-(5-Iodo-1H-indole-3-yl)-6-methyl-2-thioxo-1,2,3,4-tetrahydro-pyrimidine-5-}

\section{carboxylic acid ethyl ester $(\boldsymbol{6 h})$}

IR (KBr pellet): 3383, 3276, 3175, 3088, 1617, 1474, 1423, 1199, 1097, $746 \mathrm{~cm}^{-1} ;{ }^{1} \mathrm{H}$ NMR (DMSO- $\left.d_{6}\right): \delta 1.22\left(3 \mathrm{H}, \mathrm{t}, \mathrm{OCH}_{2} \mathrm{CH}_{3}\right), 2.40\left(3 \mathrm{H}, \mathrm{s}, \mathrm{CH}_{3}\right), 4.15\left(2 \mathrm{H}, \mathrm{q}, \mathrm{OCH}_{2} \mathrm{CH}_{3}\right)$, $6.6(1 \mathrm{H}, \mathrm{NHCH}), 6.82-7.25(6 \mathrm{H}, \mathrm{br}, \mathrm{Ar}-\mathrm{H})$ and $\mathrm{NH}), 7.9(1 \mathrm{H}, \mathrm{s}, \mathrm{NH})$. Elemental analysis (\%) calc. C 43.55, H 3.65, N 9.52, O 7.25, found C 43.52, H 3.62, N 9.53, O 7.22, and S 7.26.

\section{Antimicrobial studies}

\section{In vitro antibacterial studies}

Newly synthesized compounds 3a-d and 6a-h were screened for their in vitro antibacterial activity against Escherichia coli (ATCC 10536) and Pseudomonas aeruginosa (ATCC 9027) according to the disc diffusion method. The minimum inhibitory concentration (MIC) was determined by the serial dilution technique using dimethylsulphoxide as a solvent. Ciprofloxacin (1-cyclopropyl-6-fluoro-1, 4-dihydro-4-oxo-7-(1-piperazinyl)-3-quinoline carboxylic acid) was used as standard in these antibacterial screening studies. The MIC calculated were $100 \mu \mathrm{g} / \mathrm{mL}$ for compounds 3a-d, $50 \mu \mathrm{g} / \mathrm{mL}$ for compounds 6a-d and $75 \mu \mathrm{g} / \mathrm{mL}$ for compounds $\mathbf{6 e - h}$.

\section{In vitro antifungal studies}

The antifungal screening studies of compounds 3a-d and $\mathbf{6 a - h}$ were performed by the standard agar disc diffusion method. Seven days old cultures of Aspergillus niger (ATCC 16404) and Fusarium oxysporum (isolated from rotten fruits) were used as test organisms. They were grown on potato dextrose agar medium. The MIC values were determined by serial dilution technique using dimethylsulphoxide as solvent. The growth of microorganisms was determined visually and the lowest concentration that inhibits the growth of microorganisms for 24 hours at $37{ }^{\circ} \mathrm{C}$ was taken as the MIC. The standard used for 
comparison in antifungal screening studies was carbendazim (1H-benzimadazol-2-yl carbamic acid methyl ester). The MIC calculated were $100 \mu \mathrm{g} / \mathrm{mL}$ for compounds 3a-d, $75 \mu \mathrm{g} / \mathrm{mL}$ for compounds $6 \mathbf{a}-\mathbf{d}$ and $50 \mu \mathrm{g} / \mathrm{mL}$ for compounds $\mathbf{6 e - h}$.

\section{Results and Discussion}

The most obvious approach for carrying out the synthesis of substituted indole dihydropyrimidines is due to potent biological activity of indoles as well as dihydropyrimidines. The synthesis begins from the commercially available indole (1), we were able to synthesize 5 -substituted indoles (2) in three steps using known protocol ${ }^{10}$. The further formylation of 2 with $\mathrm{DMF} / \mathrm{POCl}_{3}$ by Wismeyer - Hack method to obtain indole 3carboxaldehyde (3) in good yields ${ }^{11}$.

In cyclocondensation reaction of indole carboxaldehyde (3), urea or thiourea (4) and ethylacetoacetate (5) in the presence of acid catalyst by refluxing in ethanol to afford indole dihydropyrimidines $(\mathbf{6})^{12}$. The structural assignments for indole 3-carboxaldehydes (3) and indole dihydropyrimidines (6) were made by correlating ${ }^{1} \mathrm{H}$ NMR and IR data with data for corresponding compounds.

In summary, we have synthesized indole dihydropyrimidines via cyclocondensation between indole carboxaldehyde, urea or thiourea and ethylacetoacetate.

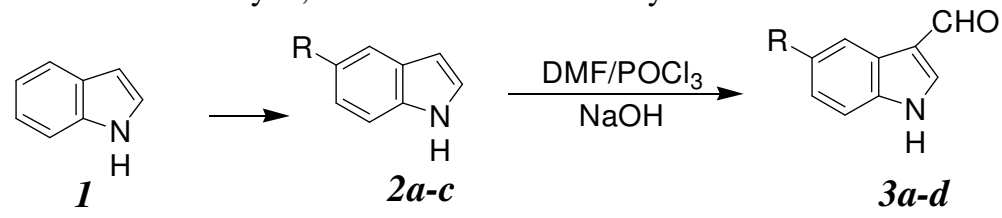

Scheme 1. Synthesis of indole-3-cerboxaldehydes.

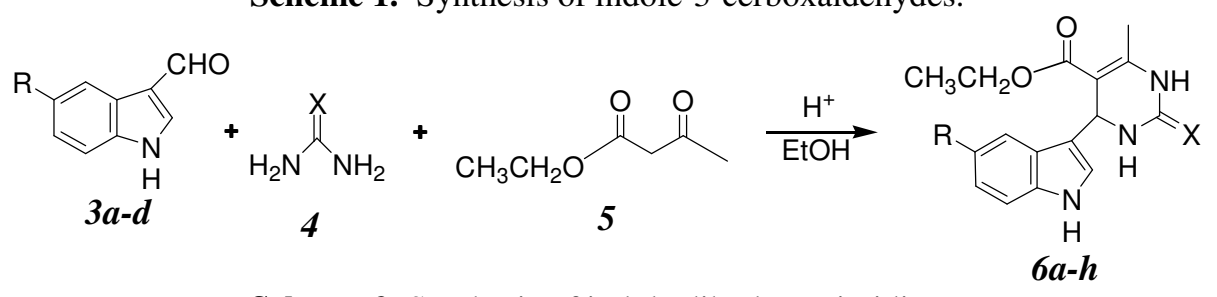

Scheme 2. Synthesis of indole dihydropyrimidines.

Table 1. Derivatives of synthesized compounds.

\begin{tabular}{cccc}
\hline Entry & Derivative & $\mathrm{R}$ & $\mathrm{X}$ \\
\hline 1 & $\mathbf{3 a}$ & $\mathrm{H}$ & - \\
2 & $\mathbf{3 b}$ & $\mathrm{Br}$ & - \\
3 & $\mathbf{3 c}$ & $\mathrm{Cl}$ & - \\
4 & $\mathbf{3 d}$ & $\mathrm{I}$ & - \\
5 & $\mathbf{6 a}$ & $\mathrm{H}$ & $\mathrm{O}$ \\
6 & $\mathbf{6 b}$ & $\mathrm{Br}$ & $\mathrm{O}$ \\
7 & $\mathbf{6 c}$ & $\mathrm{Cl}$ & $\mathrm{O}$ \\
8 & $\mathbf{6 d}$ & $\mathrm{I}$ & $\mathrm{O}$ \\
9 & $\mathbf{6 e}$ & $\mathrm{H}$ & $\mathrm{S}$ \\
10 & $\mathbf{6 f}$ & $\mathrm{Br}$ & $\mathrm{S}$ \\
11 & $\mathbf{6 g}$ & $\mathrm{Cl}$ & $\mathrm{S}$ \\
12 & $\mathbf{6 h}$ & $\mathrm{I}$ & $\mathrm{S}$ \\
\hline
\end{tabular}




\section{References}

1. Gracia M, Valverde and Torroba T, Molecules, 2005, 10, 318-320.

2. Kappe C O, Terahedron, 1993, 49, 6937-6963.

3. Matsuda T and Hirao J, Nippon Kagaku Zasshi, 1965, 86,1195-1197

4. Birgit Jauk, Tetiana Pernat and Kappe C O, Molecules, 2000, 5, 227-239.

5. Kappe C O and Farber G, J Chem Soc., Perkin Trans., 1991, 1, 1342-1344.

6. Sadanandam Y S, Shetty M M and Diwan P V, Eur J Med Chem., 1992, 27, 87-92.

7. Sukemi S and Sun H J, Org Chem., 1991, 56, 4304; Kawasaki Y, Yamashita M and Otha S, Chem Pharma Bull., 1996, 44, 1831.

8. Mieczyslaw and Makosza, Pure Appl Chem., 1997, 69(3), 559-564.

9. Lee K, Moon S J, Ha D C, Kee- In Lee, Gong Y D and Lee J C, Bull Korean Chem Soc., 2006, 27, 7.

10. Thesing J, Sembler G and Mohr G, Chem Ber., 1962, 95, 2205; Gribble G W and Nutaitis C F, Org Prep Proc Int., 1985, 17, 317.

11. Duflos M, Marie-Renee, Nourrisson J, Brelet J, Courant Guillaume Le Baut N, Grimoud and Jean - Yves Petit, Eur J Med Chem., 2001, 36, 545- 553.

12. Bose D S, Fatima L and Mereyala H B, J Org Chem., 2003, 68, 587; Lu J and Bai Y, Synthesis, 2002, 466. 


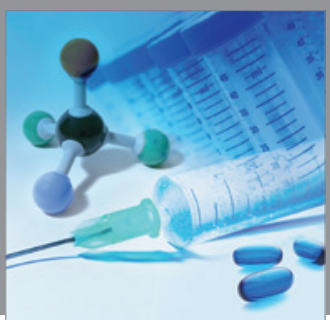

International Journal of

Medicinal Chemistry

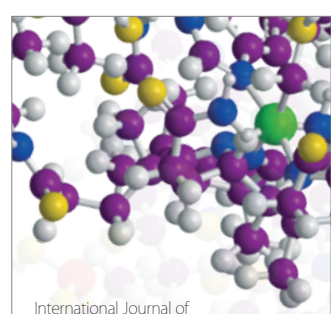

Carbohydrate Chemistry

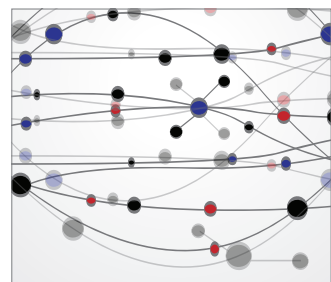

The Scientific World Journal
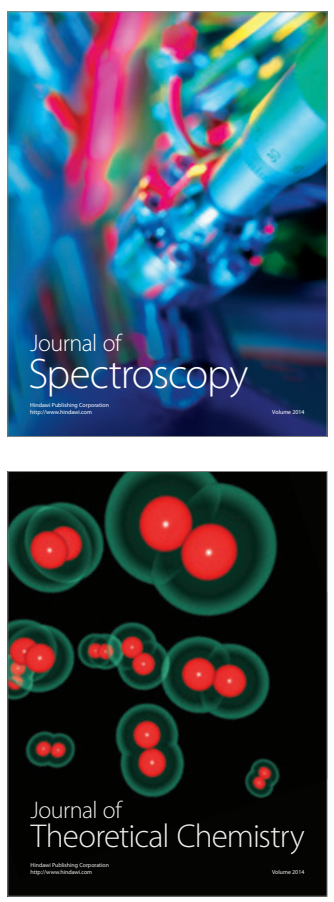
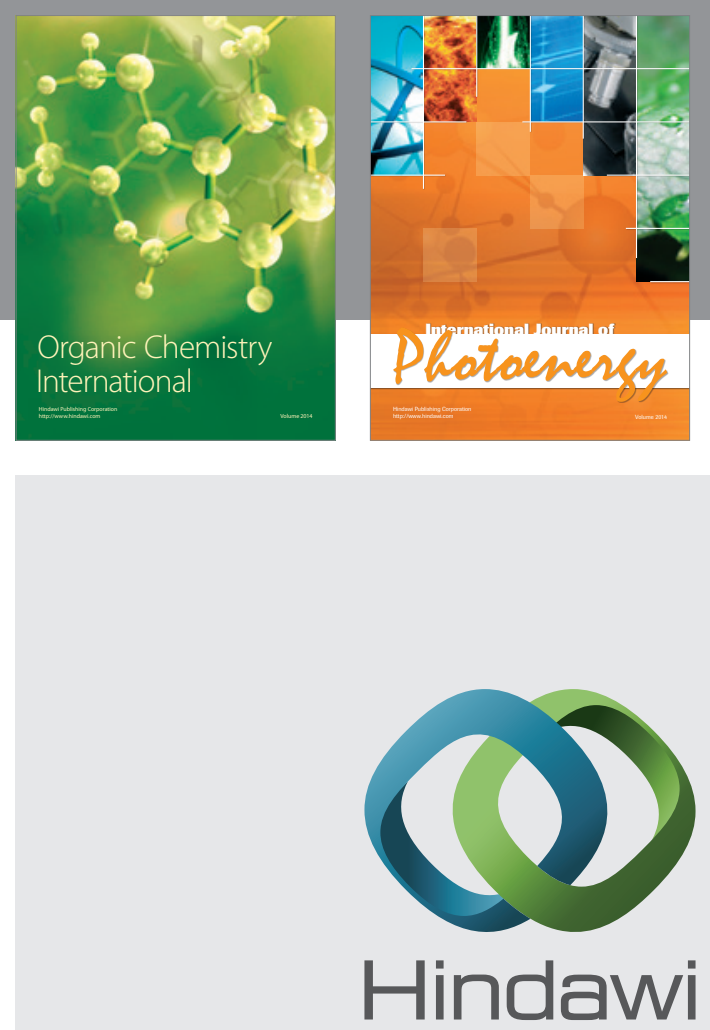

Submit your manuscripts at

http://www.hindawi.com
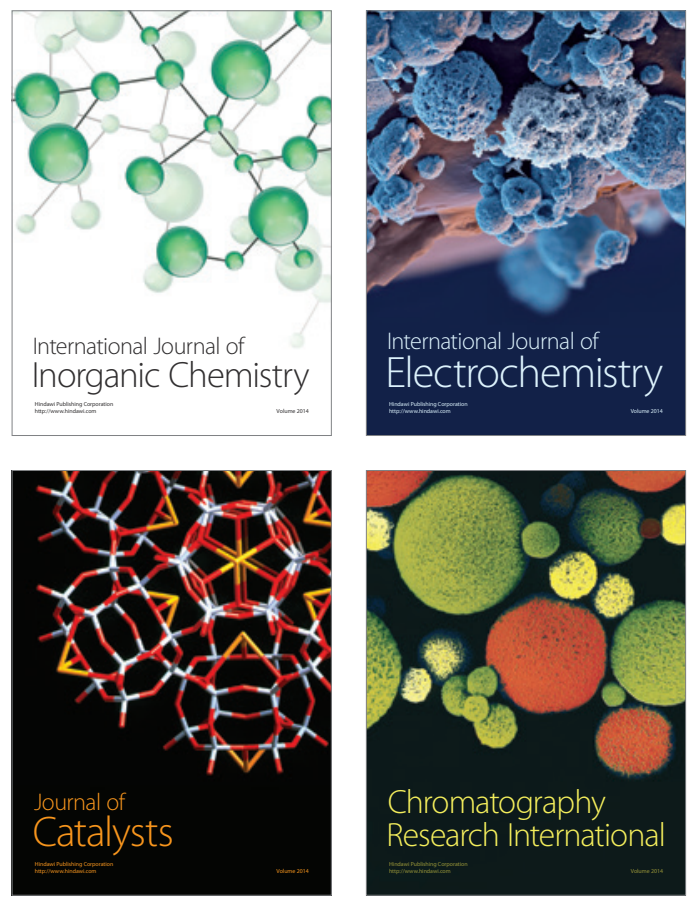
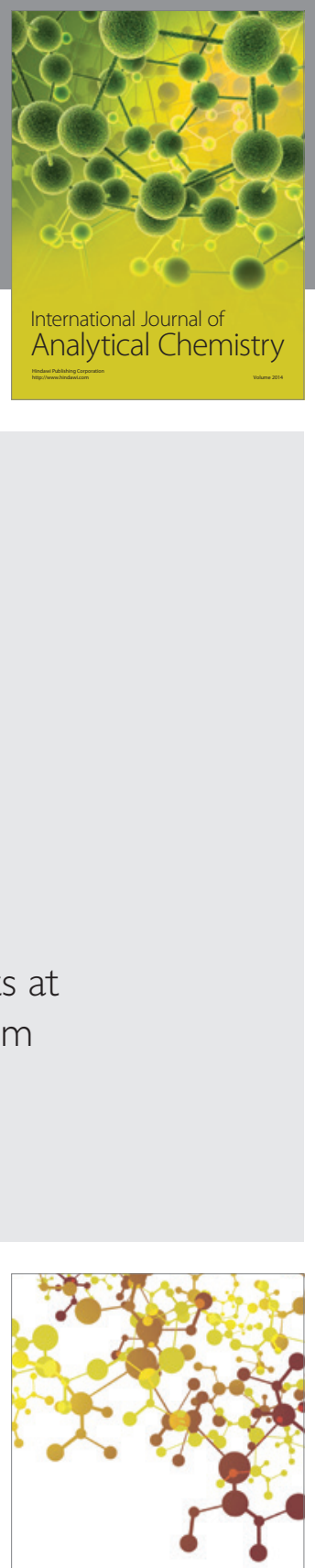

Journal of

Applied Chemistry
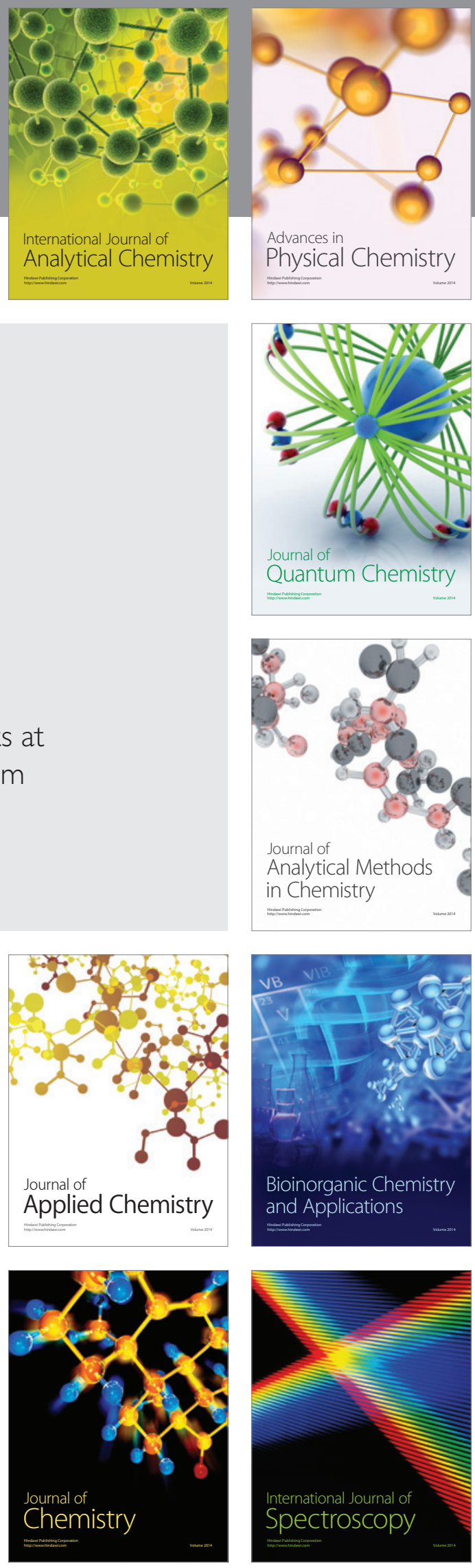